\title{
Answer to the comment of Casas et al. about González Acebrón et al.'s (2011) paper
}

\author{
Laura González-Acebrón · R. H. Gold stein · \\ Ramón Mas · José Arribas
}

The comment of Casas et al. concerns the paper published by Gønzález-Acebrón et al. (2011) and refers mostly t• their model for the structural and thermal events in the sedimentary record (Late Jurassic-Early Cretaceous) from the Cameros Basin. Their model differs significantly from the interpretations previously published by Mas et al. (1993), Guimerà et al. $(1995,2004)$ and Mas and Salas (2002). Their main concern appears to be the difference of - pinion abøut the previøusly published structural evølution -f the basin, not the results of our new study. Rather than debate the earlier, more appropriate papers, they have chosen this our marginally related paper to air their different view of the structural interpretations. Our paper did not concern evidence for interpretations of the structural evelution of this basin, which had already been published and peer-reviewed. We clearly stated that we had excluded their model for consideration relative t॰ ๑ur new data, why we had done sø, and referred to the appropriate peerreviewe literature. Thus, we must question whether this is

L. González-Acebrón (অ) · R. Mas

Departamento del Estratigrafia, Facultad de Ciencias Geológicas (UCM), Instituto de Geociencias (IGE-CSIC), C/Jose Antonio Novais 2, 28040 Madrid, Spain

e-mail: 1gcebron@geo.ucm.es

R. H. Goldstein

Department of Geology, University of Kansas, 1475 Jayhawk

Blvd., Lawrence, KS 66045, USA

J. Arribas

Departamento del Perología y Geoquímica, Facultad de Ciencias Geológicas (UCM), Instituto de Geociencias (IGECSIC), C/Jose Antonio Novais 2, 28040 Madrid, Spain the appropriate venue for airing such a debate. It appears their comment shøuld have been aimed at søe other paper with a very different focus.

As Casas et al. have pøinted out, the Camerøs Basin represents "өne of the best-known and controversial basins in the Iberian microplate". The Cameros Basin is atypical -f the different Mesøzic basins of Iberia by its very high sedimentation and subsidence rates, generating a stratigraphic sequence of more than $\mathbf{9 , 0 0 0} \mathrm{m}$ frøm Tithonian t• Early Albian. In addition, sediments were affected by lowgrade metamorphism. Given the controversial nature of this basin, it is inevitable that such debates occur, but more appropriate venues have been used in the past, going back almost 20 years.

In their comment we appreciate that Casas et al. consider that we have produced invaluable data about the thermal evolution of the basin... and an important contribution to the understanding of the post-sedimentary, preinversion processes... We agree with their opinion that research will undoubtedly add new evidence to the knowledge of hydrothermal processes in general and particularly to the paleothermal evolution of the basin. Where we disagree with them is that we have (1) inappropriately or missed references and (2) made interpretations without prior consideration $\bullet$ their model. Their model had already been evaluated and rejected in multiple previously published papers, more appropriate for debating the differences between both structural models (e.g., Mas et al. 1993; Guimerà et al. 1995; Mas et a1. 2003; Omode-Salè et al. 2011). It is on this basis that the synclinal basin model

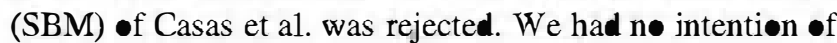
inappropriately extensive repetition of data and arguments already in the literature, in our paper. Again, our paper was n七t an appropriate venue for that. Beløw, we reply t॰ each of their comments. 
Inappropriate references

We have to disagree with the Casas et al. assertion that referencing was nøt appropriate. They apparently have taken the point of view that we should have rehashed all of the literature on the debate on the structural evølution of the basin, even thøugh that was nøt the focus of our paper. As an example of our pøint, in their paper on the structure -f the Camerøs Basin (Casas et al. 2099), we did not necessarily expect them to reference all previøus studies concerning the stratigraphy and basin structure in the Cameros Basin. Had they been practicing what they were preaching, they would have cited Mas et al. $(2002,2003$, 2004) and Guimerà et al. (2004). The paper at which their comment is directed (Gønzález-Acebrón et al. 2011) gave a fair airing to their views considering the focus of the paper. Several paragraphs in the sections of "Introduction", "Basin formation" and "Metamorphic processes and studied sections" are dedicated to introduce the idea of burial, dyname-thermal metamorphism and to discuss the model that Casas et al. maintain t• explain the Cameros Basin configuration. In these sections, the following of their papers are referred t• (Casas-Sainz and Simón-Gómez 1992; Casas-Sainz and Gil-Imaz 1998; Mata et al. 2001; Casas et a1. 2009; Del Rí et al. 2009), which adequately summarized the appropriate material for those discussions.

In addition, Casas et al. make the following assertions in relation to referencing, and we respond to each in sequence:

1. Casas et al. write that up to date, the only thørough studies of the small-scale extensional structures (namely tension gashes and microfaults) at the basin scale within the Cameros basin have been carried out by Guiraud and Seguret (1985).

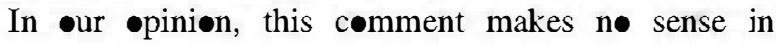
relation t॰ $\bullet$ ur paper. In $\bullet$ ur paper, we never mentioned that $\bullet$ ur work attempted to be a thorøugh study of small-scale extensional structures in the Cameros Basin or that we had been the first to do so.

2. Casas et al. write that it is not justified to reject the syncline basin model.

Multiple publications have criticized the SBM proposed by Casas et al. on the basis of mechanical flaws. These publications question that extension was produced by the action of a normal fault dipping southward and located in the Upper Triassic deposits t• produce a "simply" synclinal basin fill, as Casas et al. suggest (Casas-Sainz and Simón-Gómez 1992; Casas-Sainz 1993; Mata et al. 2001; Casas et al. 2009; amøng $\bullet$ thers). Thøse studies disprove their hyp thesis because of the presence of marine Jurassic rocks constituting the substratum thrøughøut the basin (e.g.,
Mas et al. 1993, 2003; Guimerà et al. 1995; Omøde•Salè et a1. 2011). In addition, geøløgical mapping and seismic profiles (Mas et al. 1993; Guimerà et al. 1995) reveal that architecture of the basin infill consists of a lateral juxtaposition of depositional sequences where depøcentres were løcated to the north and onlapped the Jurassic substratum. This was interpreted as a consequence of the søuthward displacement of the hanging wall including the earlier depositional sequences (e.g., Mas et al. 1993, 2003; Guimerà et al. 1995; Omøde•Salè et al. 2011). The data and arguments to reject the SBM idea have been published previøusly. It would have been in inappropriate to restate all of these in Gønzález-Acebrón et al. (2011).

3. Casas et al. write that the term "hydrothermal metamorphism" is used inappropriately. They propose that this term should be used to describe the alteration of -ceanic crust and that it is used in incorrectly in Gønzález-Acebrón et al. (2011) t• describe metamørphism in the Cameros Basin.

Hydrothermal metamorphism is defined following the recommendations from the International Union of Geølogical Sciences Subcommission on the Systematics of Metamorphic Røcks (Fetters and Desmons 2007). It is a "type of metamorphism of løcal extent caused by hot $\mathrm{H}_{2}$-rich fluids. It is typical of løcal extent in that it may be related to a specific setting or

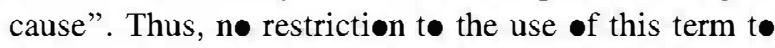
the $\bullet$ ceanic crust exists, and sø the use $\bullet$ hydrøthermal metamorphism for the Camerøs Basin is completely correct.

\section{A priori rejection of the Syncline Basin Model}

Casas et al.'s comment pøints out their main concern with Gønzález-Acebrón et al. (2011) is its aprioristic rejection of the SBM. We agree that we rejected this hypothesis at the øutset of our discussion, but do not agree that it is a cause of concern. The syncline model for Cameros Basin was rejected on the basis of an extensive literature using data other than that presented in González-Acebrón et al. (2011). There is n๑ reas to consider a disproven hyp thesis without some real reason. One merely is required to refer to it and explain why it is not being considered. That is how deductive scientific reasoning makes progress, thrøugh rejection of hypotheses. The reasons for rejection of the SBM hyp thesis can be summarized from the literature as follows:

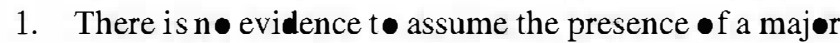
extensional fault at the northern boundary of the basin, mainly because the marine Jurassic substratum appears 
to be continuøus thrøughøut the basin. This continuity is maintained even after the basin inversion (Mas et al. 1993, 2003; Guimerà et al. 1995; Omode•-Salè et al. 2011).

2. There is northward migration of successive depositional sequences and depocentres, manifested by their -nlap ont• the pre-basin Mesøeic substratum and -nlap $\bullet$ t॰ the northern border of the basin (Mas et al. 1993, 2003; Guimerà et al. 1995; Omode-Salè et al. 2011).

3. There is a progressive spatial evølution of facies in depositional sequences, from proximal areas of depsition (i.e., coarse-graine deposits in alluvial fan systems) at the southern areas to distal facies (i.e., lacustrine) at the northern areas of the basin (i.e., Urbion Gr.; Encise Gr.; Olivan Gr.). There is n• evidence for an active source of sediments in the northern area (Alons and Mas 1993; Mas et al. 2003).

4. There is evidence of non-prograde hydrothermal alteration (Aløns-Azcárate et al. 1995; Barrenechea et a1. 1995, 2000, 2001). These authors considered the composition and permeability of sediments as main factors that control the alteration. This fact produces thermal inversion across sections in the depecentre areas (Mantilla-Figuerøa et a1. 1998, 2002; Barrenechea et al. 2001) and postrift age (Casquet et al. 1992).

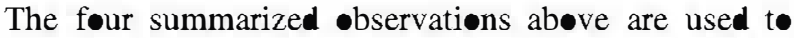
disprøve a "simply" extensional synclinal basin model. In the literature, we have $\bullet$ ffere an alternative hyp thesis consisting $\bullet$ superimp $\bullet$ sition $\bullet$ sedimentary sequences but with consistent depecenter migration to the north. This hypothesis explains data summarized abøve and supports the idea that sedimentary infill was the consequence of synsedimentary hanging-wall displacement to the Søuth. Thus, the Cameros Basin can be considered as an extensional ramp syncline basin, formed on a south-dipping ramp associated with a buried horizontal extensional fault several kilømeters deep (Mas et a1. 1993, 2003; Guimerà et al. 1995; Omode-Salè et a1. 2011).

On the basis $\bullet$ the comment $\bullet$ Casas et al., it is clear that they still consider the syncline basin model to be viable. It is valuable for the readers t• see tw॰ such differing interpretations can arise. The explanation is related to differences in basic mapping and stratigraphic analysis that can be summarized with the following key points:

1. As explained earlier, there is one essential observation that is the key to understand the tw $\bullet$ differing interpretations. Casas et al. do nøt recognize or consider the onlap of the Encis॰ Gr. (including Leza Fm.) on the northern border of the basin, as demonstrated by Guimerà et al. (1995) and Mas et al. (2002; its Fig. 2b).
2. Furthermore, Casas et al. (2009) consider that the Oncala Gr. crøps øut along the northern border of the basin and dipping southward (see Fig. 3a frøm Casas et al. 2009), but it is the Encisø Gr. that is found.

3. In addition, Casas et al. consider "the existence of continuous øutcrops of the syn-rift sequence all along the northern basin border". We think this •bservation is in error and leads to significant misinterpretations. The mapping used by Casas et al. (Mata et al. 2001; Villalain et al. 2003; Casas et al. 2099) corresponds t• an $\bullet$ ld geølogical concept $\bullet$ the sedimentary record $\bullet$ the basin, possibly obtained from the publications -f the Spanish Geøløgical Maps, especially those of

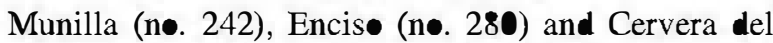
Rí Alhama (n๑. 281) from the MAGNA serie (IGME 1981, 1982, 1990, respectively).

4. The more recent stratigraphic framework of the Cameres Basin can be analyzed in several newer publications (Mas and Salas 2002, p. 285; Mas et a1. 2003, 2004, p. 506. All of these publications demonstrate that the Oncala Gr. does nøt crøp in the northern part of the basin, as Casas and co-authors maintain. The carbønate units crøpping out in this area correspønd to the Leza Fm., a lithosøme included in the Encis• Gr., recently dated by Suárez et al. (2010) as Barremian-Aptian. We speculate that Casas and cœ-authors may have confused this carbonate formation with carbonates from Oncala Gr. This speculation is backed up by observing Fig. $3 \mathrm{a}$ and $\mathrm{b}$ in Casas et al. (2009).

5. Anøther prøblem with the mapping of Mata et al. (2001), Villalain et al. (2003) and Casas et al. (2009) is that they do not recognize the onlap of the main sedimentary units (Oncala Gr., Urbión Gr., Encis• Gr. and Oliván Gr.,) •ver the Mesøzœic substratum in the northern area $\bullet$ the basin as a result of the migration

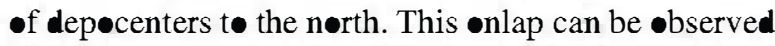
clearly along the northern border of the basin, where depositional sequences $1+2,3$ and 7 onlap progressively $\bullet$ ver the Jurassic substratum (Fig. 1 in González-Acebrón et a1. 2011). This onlap is nøt recognized in Fig. 3 frøm Casas et al. (2009), which -ffers a scheme that greatly differs from our detailed mapping $\bullet$ stratigraphic units.

6. Casas et al. have pointed that seismic reflection data "unequivecally" support their SBM, referencing the publications by Casas-Sainz and Gil-Imaz (1998) and Casas et al. (2009). However, these authors forget the seismic interpretations of Guimerà et al. (1995) where a seismic reflection analysis clearly support the progressive northward onlap of depositional sequences -ver marine Jurassic deposits at the basin substratum (Fig. 6 •f Guimerà et al. 1995). 
Thus, the issues with the stratigraphic, mapping and seismic observations summarized above can clearly lead to an incorrect model for basin evolution. Once such model is proposed, as Casas et al. have pøinted øut, one can find paleomagnetic data (Villalaín et al. 2003), mineral assemblages and fluid inclusion microthermometry (Mata et al. 2001), and even some of the seismic observations (Casas et al. 2009) that are consistent with it. Consistency with a hypothesis does not prove it to be correct, however. As summarized in the foregøing, other observations can disprove it.

Finally, the comment of Casas et al. $\bullet$ ffers a last figure with tw cross sections rying to express the two opposing basin models proposed for the Cameros Basin. Unfortunately, Casas et al., represent our model incorrectly. We have already published the correct relationship in Fig. 12 - f Gønzález-Acebrón et al. (2011) and do not see why that would modify our view and represent it as ours. The extensional ramp-flats configuration that we propese is not at a continuous level that extends toward the north. In contrast, the northern flat connects with the normal listric faults outside the Cameros Basin toward the north. These normal faults are responsible of the configuration of satellite basins located between the Cameros Basin and the Vasc-Cantabrian Basin at the nørth of the Iberian plate.

\section{Comment on thermal data}

Casas et al. question the position of samples from GønzálezAcebrón et al. (2011) within the basin (gray star in Fig. 12). We must say that the stratigraphic location of the samples is abselutely correct: they correspond to the Tera Gr., and thus, their position in Fig. 12 is completely well supported.

On the other hand, in several papers, several authors (e.g., Mata et al. 2001) have tried to demonstrate "the close relation between paleotemperatures and the position within the stratigraphic sequences" as a prograde sequence. Casas et al. use this paleotemperature data as support for their SBM and disprøof of our model for hydrothermal metamorphism (e.g., Mata et al. 2001). Oddly, Mata et al. (2001) supported a mixed hypothesis with a prograde sequence everprinted by syn to retrograde hydrothermal events; thus, the hydrothermal metamorphism is in some way accepted by these authors.

Furthermore, an analysis of the position of samples for paleotemperature analysis in the stratigraphic framework used in Mata et al. (2001) shows that they are not part of a local vertical succession (Fig. 2A and B in Mata et al. 2001). Their •ldest samples (T1 to T4 frøm the Tera Gr.) were collected close to the El Pegado anticline, where hydrothermal alteration processes reach the anchizoneepizone boundary (i.e., Barrenechea et a1. 2001; Mantilla-
Figuerea et al. 1998, 2002). In contrast, their younger samples (Urbión and Oliván Gr.) were cøllected far away representing a vertical sample succession, but shifting laterally more than $25 \mathrm{~km}$. On the basis of this fact, an incorrect prograde sequence was deduced.

Comments abøut the age of the metamorphism are not justified as far as the age obtained by Del Rí et al. (2009) by SHRMP U-Pb dating on authigenic monazites ( $99 \pm 2$ $\mathrm{My}$ ) is inside the age range of Casquet et al. (1992) by $\mathrm{K}-\mathrm{Ar}$ in authigenic illites (108-86 My).

In addition, Casas et al. argue that chlorite is not a reliable gethermometer. In our paper, ge thermømetric data from chlorites are cited together with illite crystallinity from Mantilla-Figuerøa (1999) and Barrenechea et al. (2001). B th types of data point to equivalent temperatures. We considered useful to refer the chlorite data in order to show all the available geothermometers in the study area, independently of its level of reliability.

Casas et al. consider that almost $400 \mathrm{~m}$ is a thin sedimentary sequence (Fig. 11 of González-Acebrón et al. 2011) to calculate thermal gradients among fracture fillings. However, in our work, we have demonstrated that variations in paleotemperature data in veins crossing this sedimentary thickness exist. Thus, we can accept these gradients. In addition, changes in gradient between both sections evidence the hydrothermal metamorphism.

Casas et al. comment that in this case "it seems admissible for the authors to consider sedimentary bodies to be superimposed in the vertical". This sentence makes no sense and indicates a scale confusion of these authors between the architecture of sedimentary bodies in the local analyzed area and the architecture of depositional sequences in the whole basin.

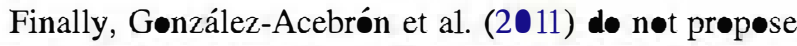
three hydrothermal events as Casas et al. stated. Only twe thermal events are propesed in this paper.

\section{Conclusion}

In conclusion, we would like to thank Casas et al. (2009), Villalain et al. (2003) and Mata et al. (2001) for the quality data they have provided toward understanding the Cameros Basin. We believe that their criticism that we did reference all of the discussion of the debate on the Cameros Basin is misplaced. They have projected this structural debate ont a paper of much different focus and scope. We add that the scientific methød is one of disprøo of hyp theses. Their basin model has been disproven in prior publications. The fact that some data are consistent with this discredited model does not make it correct. Finally, we appreciate Casas et al.'s compliments on the detailed petrographic and geothermometric data we have produced. We disagree with 
their SBM, but we agree with them that there is much yet to be done to fully understand this complex system. Our work has shown and characterized two different hydrothermal events of Cretaceous and Eøcene age. But a more detailed petrographic study integrating variøus structural elements, geøthermømetry and thermøchrøn॰metry will undøubtedly result in this already complex story evelving further.

Acknowledgments Funding for this research was provided by the Spanish DIGICYT projects BTE 2001-026, CGL 2005-07445-C0302/BTE, CGL2008-01648/B TE, CGL2011-2270//BTE and by UCMCM (Universidad Complutense-Madrid Community) for the Research Group "Sedimentary Basin Analysis". The authors would like to thank Casquet, C. for his useful suggestions.

\section{References}

Alonso-Azcárate J, Barrenechea JR, Rodas M, Mas R (1995) Comparative study of the transition between very low grade metamorphism and low grade metamorphism in siliciclastic and carbonate sediments. Early Cretaceous, Cameros Basin (North Spain). Clay Miner 30:407-419

Barrenechea FJ, Rodas M, Mas JR (1995) Clay mineral variation associated to diagenesis and low grade metamorphism of early cretaceous sediments in the Cameros Basin, Spain. Clay Miner 30:89-103

Barrenechea FJ, Rodas M, Frey M, Alonso-Azcárate J, Mas JR (2000) Chlorite, corrensite and chlorite-mica in Late Jurassic fluviolacustrine sediments of the Cameros Basin of Northeastem Spain. Clay Clay Miner 48(2):56-265

Barrenechea FJ, Rodas M, Frey M, Alonso-Azcárate J, Mas JR (2001) Clay diagenesis and low-grade metamorphism of Tithonian and Berriasian sediments in the Cameros basin. Clay Miner 36(3):325-333

Casas AM, Villalaín JJ, Soto R, Gil-Imaz A, del Río P, Femández G (2009) Multidisciplinary approach to an extensional syncline model for the Mesozoic Cameros Basin (N Spain). Tectonophysics 470:3-20

Casas-Sainz AM (1993) Oblique tectonic inversion and basement thrusting in the Cameros Massif (Northern Spain). Geod Acta $6(3): 202-216$

Casas-Sainz AM, Gil-Imaz A (1998) Extensional subsidence, contractional folding and thrust inversion of the Eastern Cameros Basin, Northem Spain. Geol Rudsch 86:802-818

Casas-Sainz AM, Simón-Gómez JL (1992) Stress field and thrust kinematics: a model for the tectonic inversion of the Cameros Massif (Spain). J Sruct Geol 14(5):521-530

Casquet C, Galindo C, González-Casado JM, Alonso A, Mas R, Rodas M, García E, Barrenechea JF (1992) El metamorfismo en la Cuenca de Los Cameros. Geocronología e implicaciones tectónicas. Geogaceta 11:22-25

Del Río P, Barbero L, Mata P, Fanning CM (2009) Timing of diagenesis and very low-grade metamorphism in the eastem sector of the Sierra de Cameros (Iberian Range, Spain): a U-Pb SHRIMP study on monazite. Terra Nova 21:438-444

Fetters D, Desmons J (2007) Metamorphic rocks: a classification \& glossary of terms. Cambridge University Press, Cambridge

González-Acebrón L, Goldstein RH, Mas R, Arribas J (2011) Criteria for recognition of localization and timing of multiple events of hydrothermal alteration in sandstones illustrate by petrographic, fluid inclusion, and isotopic analysis of the Tera Group, Northem Spain. Int J Earth Sci 100:1811-1826
Guimerà J, Alonso A, Mas R (1995) Inversion of an extensional-ramp basin by a newly forme thrust: the Cameros Basin (N Spain) In: Buchanan JG, Buchanan PG (eds) Basin inversion. Geological Society Spec. Publ. 88:433-453

Guimerà J, Mas JR, Alonso A (2004) Intraplate deformation in the NW Iberian Chain: mesozoic extension and Tertiary contractional inversion. J Geol Soc Lond 161:291-303

Guiraud M, Seguret M (1985) A realising solitary overstep model for the late Jurassic-early cretaceous (Wealdian) Soria strike-slip basin (Northern Spain). SEMP Special Pub1 37:159-175

IGME (1981) Mapa geológico de Enciso (no. 280)

IGME (1982) Mapa geológico de Cervera del Río Alhama (no. 281)

IGME (1990) Mapa geológico de Munilla (no. 242)

Mantilla-Figueroa LC (1999) El metamorfismo hidrotermal de la Sierra de Cameros (La Rioja-España): Petrología, Geoquímica, Geocronología y contexto estructural de los procesos de interacción fluido-roca. Ph.D. Thesis UCM, $361 \mathrm{pp}$

Mantilla-Figueroa LC, Casquet C, Mas JR (1998) Los paleofluidos del Grupo Oncala, Cuenca de Cameros (La Rioja, España): Datos de inclusiones fluidas, isótopos de oxígeno y SEM. Geogaceta 24:207-210

Mantilla-Figueroa LC, Casquet C, Galindo C, Mas JR (2002) El metamorfismo hidrotermal cretácico y Paleógeno de la Cuenca de Cameros (Cordillera Ibérica, España). Zubía. Instituto de Estudios Riojanos 14:143-154

Mas JR, Salas R (2002) Lower cretaceous in the Iberian Basin. In: Gibbons W, Moreno T (eds) Geology of Spain. Geol. Soc. Lon., pp 284-288

Mas JR, Alonso A, Guimerà J (1993) Evolución tectonosedimentaria de una cuenca extensional intraplaca: la cuenca finijurásicaeocretácica de Los Cameros (La Rioja-Soria). Rev Soc Geol Esp $6(3-4): 129-144$

Mas JR, Benito MI, Arribas J, Serrano A, Guimerà J, Alonso A, Alonso-Azcárate J (2002) La Cuenca de Cameros: desde la extensión finijurásica-eocretácica a la inversión terciariaimplicaciones en la exploración de hidrocarburos. Zubía. Instituto de Estudios Riojanos 14:9-64

Mas JR, Benito MI, Arribas J, Serrano A, Alonso A, Alonso-Azcárate J (2003) The Cameros basin: from late Jurassic-early cretaceous extension to tertiary contractional inversion-implications of hydrocarbon exploration. In: AAPG international conference and exhibition. Barcelona, Spain (geological field trip 11)

Mas JR, García A, Salas R, Meléndez A, Alonso A, Aurell M, Bádenas B, Benito MI, Carenas B, García-Hidalgo JF, Gil J, Segura M (2004) Segunda fase del rifting: Jurásico SuperiorCretácico Inferior. In: Vera J (ed) Geología de España. Sociedad Geológica de España, Instituto Geológico y Minero, 884 pp

Mata MP, Casas AM, Canals A, Gil A, Pocovi A (2001) Thermal history during Mesozoic extension and tertiary uplift in the Cameros Basin, northern Spain. Basin Res 13:91-111

-modeo-Salè S, Arribas J, Guimerà J, Mas R, López V, Quijada IE, Suárez-González P (2011) The architecture of depositional sequences in an inverted rift basin: tectonic controls and genetic insight (the late Jurassic-early cretaceous Cameros basin, $\mathbf{N}$ Spain). 28th IAS meeting of sedimentology 2011, Zaragoza, Spain (abstracts book: 445)

Suárez P, Quijada E, Mas JR, Benito MI (2010) Nuevas aportaciones sobre la influencia marina y la edad de los carbonatos de la Fm. Leza en el sector de Préjano (SE de La Rioja). Cretácico Inferior, Cuenca de Cameros. New contributions to the marine influence and the age of the Leza Fm carbonates in the Préjano area (SE La Rioja). Lower cretaceous, Cameros Basin. Geogaceta 49:7-10

Villalaín JJ, Fernández-González G, Casas AM, Gil-Imaz A (2003) Evidence of a cretaceous remagnetization in the Cameros Basin (North Spain): implications for basin geomery. Tectonophysic 377:101-117 